\title{
Between tradition and renewal: Some considerations about the use of tradition in reformed theology
}

\author{
Author: \\ Willem van Vlastuin ${ }^{1,2}$ \\ Affiliation: \\ ${ }^{1} J o n a t h a n$ Edwards Centre, \\ Benelux at Vrije Universiteit, \\ Netherlands \\ 2Jonathan Edwards Centre, \\ University of the Free State, \\ South Africa \\ Correspondence to: \\ Willem van Vlastuin \\ Email: \\ w.van.vlastuin@vu.nl \\ Postal address: \\ Jachtlaan 18, 8091 BM \\ Wezep, Netherlands \\ Dates: \\ Received: 24 July 2012 \\ Accepted: 25 June 2013 \\ Published: 29 Aug. 2013 \\ How to cite this article: \\ Van Vlastuin, W., 2013, \\ 'Between tradition \\ and renewal: Some \\ considerations about the \\ use of tradition in reformed \\ theology', In die Skriflig/In \\ Luce Verbi 47(1), Art. \#111, \\ 8 pages. http://dx.doi.org/ \\ 10.4102/ids.v47i1.111

\section{Copyright:} \\ c) 2013. The Authors. \\ Licensee: AOSIS \\ OpenJournals. This work \\ is licensed under the \\ Creative Commons \\ Attribution License.
}

Read online:
In the theology and practice of the Christian church a tension between tradition and renewal exists. This essay focuses on this tension to provide a first step of methodological reflection to deal with it. Firstly, this tension is illustrated from the reformed perspective of sola scriptura that led to criticism of the tradition on the one hand, whilst understanding the reformed movement as part of the tradition on the other hand. A danger of unqualified sola scriptura is subjectivity. Subsequently, the importance of tradition is elaborated from the perspective of the church as the body of Christ across all ages. This implies that Christians should study and love the traditional theology because of the fundamental unity of the church that transcends cultural diversity. Rejecting tradition will cut the church from its historical and spiritual roots. Thirdly, this raises the question whether the church is imprisoned by tradition, as well as the problem of the relation between tradition and renewal. In response, it is argued that the doctrine of incarnation guarantees openness to history. With the help of the philosophical and Christian view on structural contingency, the belief that tradition is principally open to renewal is defended. Some examples are given as illustrations of how classic theological concepts can be reframed in our postmodern context. The last part of this essay concludes with the insight of Cyprian that only the conveyed tradition can be renewed, implying that renewal is in essence not a new theology, but a new application of apostolic theology.

Tussen tradisie en vernuwing: Enkele oorwegings in verband met die gebruik van tradisie in die gereformeerde teologie. Hierdie artikel fokus op die spanning tussen tradisie en vernuwing in die praktyk van die Christelike kerk. Eerstens word die probleem vanuit die reformatoriese perspektief van die sola scriptura geillustreer, wat aan die een kant tot kritiek op die tradisie gelei het, maar terselfdertyd word die reformatoriese beweging as deel van die tradisie verstaan. Die gevaar van 'n ongekwalifiseerde handhawing van die sola scripturaoortuiging is subjektiwiteit. Vervolgens word die belangrikheid van die tradisie uitgebrei vanuit die perspektief van die kerk as liggaam van Christus oor alle eeue. Dit impliseer dat Christene tradisionele teologie behoort te bestudeer, omdat die fundamentele eenheid van die kerk kulturele diversiteit oorkom. Die verwerping van die tradisie sal gevolglik die kerk van sy geestelike wortels afsny. Derdens bring dit die vraag na vore of die kerk deur tradisie gevange gehou word. In hierdie verband wys die artikel daarop dat die leer van die inkarnasie openheid ten opsigte van die geskiedenis waarborg. Met behulp van die Christelike siening van strukturele gebeurlikheid, word die oortuiging dat die tradisie prinsipieel vir vernuwing oop is, verdedig. ' $n$ Paar voorbeelde word gegee om te illustreer hoe klassieke teologiese konsepte in ons postmoderne tyd benut kan word. Die artikel sluit af met 'n verwysing na die insig van Siprianus, naamlik dat net die oorgelewerde tradisie vernuwe kan word. Dit impliseer dat vernuwing essensieel nie 'n nuwe teologie is nie, maar 'n nuwe toepassing van die klassieke teologie.

\section{Introduction}

The Dutch professor, Graafland (2001:53), complained that the traditional scholastic forms of the confession were a blockade for the understanding of the Bible. This complaint indicates that in Christian practice or theology the power of traditions can function as a hindrance for biblical renewal. Traditionalism can become an anti-Christian attitude as the history of apartheid in South Africa, in which theological arguments were used to justify unrighteous structures, has shown. It is also conceivable that conservative people underestimate the real value of the great Christian tradition in absolutising certain minor aspects of tradition.

On the other hand, Christians stress sola scriptura in such a way that they do not have any respect for traditions and seek the essence of Christianity in renewal. They are oversensitive for the maintaining of traditional theology on the one hand, but on the other hand they are open for every concept of renewal and they accept these concepts in an uncritical way. It is conceivable, 
especially in our era of individualism that Christians are not conscious of the tradition to which they belong so that the great riches of the Christian tradition are neglected, denied and unemployed.

These extreme positions regarding traditions cause tension between Christians. These positions cannot simply be placed against each other as if the traditionalist is the real Christian, or the other way around. A concept to deal with these questions in the tradition of theological understanding is developed in this article.

In developing this concept, I will elaborate on the use of tradition. Firstly, I will problematise the use of tradition from the perspective of reformed theology. Secondly, I will delve into the theological justification of the use of tradition. Thirdly, I will investigate how tradition can be a catalyst for renewal.

\section{The problem of tradition in reformation}

It is a striking phenomenon that reformed theologians discuss the possibilities of the use of tradition in contemporary theology, ${ }^{1}$ because Sola Scripture belonged to the essence of the reformation to understand itself as a movement that went back to a real, biblical and sober Christianity, which could be found in the early church.

The ideal of going back to the original Christian faith implied a new return to the Scriptures (cf. Jn 5:39). Melanchthon (1521:W 6-8) made it explicitly clear in his Loci Communes that his theological work was not meant to lead students away from the Scriptures in dark and difficult disputes, but as a stimulus for reading the Scriptures. We find the same in the foreword of Calvin's Institutes (1559:2-3) ${ }^{2}$ in which he explained that his theological work was intended to give directions for the understanding of the Word of God.

This direct appeal to the Word of God in the reformation movement can be traced back to the experience of the power of the Word in the life of Martin Luther. Against the church of the Middle Ages, the monk of Wittenberg was fully convinced that the authority of the Word could not be equalled by the authority of the church. The background of this assurance was the distinction between the Creator and his creatures, which guaranteed that the Word of the God was of another quality than inventions of human beings (WA $18: 620-630) .^{3}$

1.The 8th Conference of Protestant Theological Faculties from Central and Eastern Europe and the Netherlands at Debrecen in 2012 thematised tradition. Cf. with regard to the problem of tradition Van den Brink and Van der Kooi (2012:76-78, 172-173, 360-362) and Van de Beek (2012:195-198, 270).

2.For quotations from Calvin's works, I have included references to the Latin edition of his works, Joannis Calvini opera quae supersunt Omnia (hereafter referred to as $\mathrm{CR})$. For quotations from the Institutes, I will refer directly to the definitive version of). For quotatis work.
of this

3.Luther develops his thoughts about the value of God's Word in the conflict with Erasmus. For references to Luther's works, I make use of the Weimarer Ausgabe, (hereafter referred to as WA).
This movement back to the Scriptures implied a concentration and also a reduction of the theological themes under discussion. The distrust of speculative theological disputes lead to a concentration on soteriological themes (Lohse 1995:48-49, 53). Melanchthon (1521:O 3) criticised Johannes Damascenus because of his excessive philosophising and Petrus Lombardus, because he valued human opinions above the Word of God. Publicly, he (Melanchthon ibid:O 9 , 13) asked what scholastic theologians have achieved through many centuries in disputing the natures of Christ and the essence of the incarnation. In contrast to this inanibus vocabulis [chatter, empty words], he (Melanchthon ibid:O 13) formulated the knowledge of Christ's benefits as the underlying principle in theology, practically worked out (Melanchthon ibid:O 4,12) in themes such as sin, law, grace, faith, love and hope.

The same attitude is recognisable in Calvin's works. In his commentary on Jeremiah 23:24 (CR LXVI:232), he rejects speculative reasoning about the ubiquity of God, because the aim of Scripture is to teach what is profitable for piety. ${ }^{4}$ This is only one example. It became characteristic for the reformation (CR XXXIV:457-534) to purify Christianity from all excessive theological baggage in cults and doctrines and to return to the doctrines and practices of the early church, which was apparently judged as a pure church. ${ }^{5}$

According to the consciousness of the reformers, the concept of renovatio was a threat to the Christian faith. Although there was a difference between Luther and Calvin, a suspicious and reserved attitude towards theological tradition was commonplace. The discovery of the fresh streams of the Scripture stood in a relation of tension with tradition.

Despite this critical attitude towards speculative theology and his explicit desire to return to the doctrines of the early church, Calvin had made use of several insights of the scholastic tradition. The rejection of the scholastic tradition was not a general rejection, but it concerned specifically a rejection of the school of Sorbonne (Muller 2000:39-61), ${ }^{6}$ characterised by Calvin (Inst. 3.15.7) as the 'mother of all errors'. The criticism concerning this school does not imply, however, that the reformer dismissed scholastic theology as such. In his way of reasoning, Calvin sometimes uses a scholastic style instead of an oratory style. In Calvin's oeuvre (CR LXXXIII:163; Inst. $1.16 .9,2.12 .1)$ there are several examples in which he refers to the distinctions of the scholastics in a positive way. In the doctrine of God and the trinity there was continuity with the church of the Middle Ages.

This insight clarifies the point that Scripture and tradition were interrelated at the time of the reformation. Although

4.Compare Calvin's criticism of philosophers in Inst. 1.15.6-7.

5.In Supplex exhortation ad invictissimum caesarem carolum quintum et illustrissimos principes alisque ordines (CR XXXIV:457-534) reference is made on a number of occasions to better times of the church of Christ (pp. 458, 473, 476, 492, etc.). Van der Kooi (1999:19-20) recognises the protestant principle of reduction in the search der Kooi (1999:19-20) recognises the protestant principle of reduction in the search approach of Von Harnack (Meijering 1985) is an illustration of leaving all additions and returning to the life of Jesus.

6.Compare Steinmetz (1995:40-52; 1999) and Helm (2004:1-10). 
the reformation is well-known for the formal principle of sola scriptura, the practice of Calvin is an indication that an appeal to the Scriptures could not be isolated from being part of the theological tradition.

In contemporary theology there are several reasons to reconsider the principle of sola scriptura. In this context, one should consider the problem of subjectivism in the appeal to Scripture. Bavinck (2003:I, 583) has already acknowledged that the reformation - deliberately and freely - took its position in the religious subject, in the faith of the Christian, in the testimony of the Holy Spirit'. ${ }^{7}$ The authority of the Scripture ultimately rested on a subjective conviction (Van den Belt 2008:276).

This interpretation of Bavinck is an indication of his postKantian point of view. Although the question can be posed whether the theology of the reformation can be analysed from the schematic principle of object and subject, Bavinck is just in his interpretation that in modern and postmodern culture the appeal to the testimony of the Spirit can be used arbitrarily, which necessitates a more nuanced approach towards sola scriptura.

Other developments in modern times also problematised the direct appeal to Scripture. Firstly, Die Krise des Schriftprinzips [the crisis of the principle of the Scripture] between the reformation and the 21st century increased the problematic character of the appeal to Scripture (Pannenberg 1979). ${ }^{8}$ Secondly, the acknowledgement of the historic character of Scripture, which means that Scripture itself participated in a process of tradition, underlined the complexity of the relationship between Bible and tradition. ${ }^{9}$ What we have in Scripture is the result of a process of many centuries in which there was an interaction between debate, witness, contradiction and call. Thirdly, in modernity the presupposition of a universal foundationalism reigned in which an appeal to common rationalistic principles could be made. Many times the appeal to Scripture was understood as such a rationalistic principle. In postmodern culture this foundationalistic appeal is wavering (Van den Toren 2011:11-12), which problematises the appeal to Scripture. On the one hand, this development in postmodern culture leads to a re-evaluation of tradition, but on the other hand traditional truth is understood in a relativistic and pluralistic perspective. This most recent development in postmodern culture leads to relativism and scepticism concerning truth. Bavinck has already pointed this problem out. As a counterbalance to extreme subjectivism and as a formal correction to Calvin, Bavinck (2003:I, 564, 585) ${ }^{10}$ underlined that Christian theology is intimately bound up with the

7.Compare Van der Kooi (2008)

8.The historical-critical approach of the Bible can be criticised, but that is outside the scope of this essay.

9.1 Corinthians 11:23 is an example that Paul teaches what he received in the way of tradition. Irenaeus (AH 3.6.1) wrote: 'Apostolic tradition exists in the church and is a permanent feature among us. It is found in the Scriptures written by the apostles.' See also Van der Kooi (2006:191-196). Van den Belt (2007:359-360) underlines that the Spirit leads the process of the tradition of Scripture.

10.Compare Van den Belt (2008:266, 281-283, 312). church. He stressed the pedagogical value of the church for faith, however, without completely incorporating the community in the witness of the church, so that the principal order remained personal faith, and then church.

These problems concerning the direct personal appeal to Scripture, the worth of tradition and the danger of subjectivism, illustrate the tension between the personal testimony of the Spirit in acknowledging the authority of Scripture on the one hand and the esteem of tradition on the other. This tension emphasises that the use of theological tradition is complex and calls for a nuanced understanding of the usefulness of tradition and a theological justification to which we turn in the next paragraph.

\section{The theological justification of the use of tradition}

Rowan Williams (2005) has developed a concept that deals with the foregoing questions. In his book, Why study the past? The quest for the historical church Williams elaborates on the unity of the church in every era, expressed in the concept of the body of Christ (cf. 1 Cor 12:12-31). The body of Christ is the work of God, without denying that the church exists in a human form. Belonging to the body of Christ implies that history is interpreted from the perspective of the death and the resurrection of Christ. ${ }^{11}$

Christians in the Early Church refused to share in the public cults of the empire, because they understood themselves as members of the kingdom of Christ (Williams 2005:ch. 2). The later debates about the nature of Christ are to be interpreted in relation to the church's identity in Christ. Because an earthly Saviour could not guarantee the citizenship of the heavenly kingdom, believers of that age were convinced of a Saviour outside of creation. Only in this way could the martyrs of the past be justified, and therefore the church of that time was eager to confess the deity of Christ.

Williams (2005:ch. 3) outlines the history of the reformation in describing how the body of Christ did not really function in the church of the Middle Ages because of the division between clergy and laity. In addition, the upsurge of the cities, lawyers and rulers undermined the absolute character of the public church in the Middle Ages. Luther's proclamation of God's free grace of justification underlined that the structures of the church did not correspond with God's deeds, because the church had become too much of a worldly human institution. All these developments made the reformation, above all, a revival of the identity of the church as the body of Christ (cf. Van 't Spijker 1986:120, 133). ${ }^{12}$

However, the question remains as to whether the former archbishop of Canterbury has done justice to the self-

11. Williams does not elaborate on the question whether the church is the body of the incarnated Christ or the glorified Christ - the first can lead (Van't Spijker 1981:170171) to a deification of the human nature of the church.

12.The mystical aspect of the church in Calvin does not imply the denial of history. The church was suprahistorical and historical at the same time (Van 't Spijker 1986:93-94). 
awareness of the reformers who understood their conflict with the church of the Middle Ages also as a conflict concerning the authority of the Scriptures and the soteriological theme of justification by faith. Nevertheless, the theologoumenon of the body of Christ is an important eschatological and transcendental reality (cf. Ro 6:5; Eph 2:6). From the perspective of the New Testament, the work of the Spirit is focused on individual faith, but this is not the starting point in theology (cf. Van der Kooi 2008:111-112). Understanding the individual faith as starting point in theology would bring an anthropocentric shift in the theocentric character of the New Testament. Thinking from a Trinitarian perspective brings with it an acknowledgement of the leading of the Spirit in the community of the church over and above his leading in the lives of individuals, and a consciousness of the suprapersonal character of the community of saints.

Strikingly enough, although the reformers were in their context focused on the relativisation of the massive understanding of the church as the body of Christ, this understanding of the church was not absent in their theology..$^{13}$ If they had understood their theology in an individualistic way, they should have pleaded for congregationalism and they could not have resisted Anabaptism.

Searching for the secret of this resistance to individualism, the notion of unio mystica [mystical union] can be mentioned. Especially for Calvin, the theological use of this notion was an important principle in his theology in which the union with believers of all times was included, although he did not mention it explicitly. ${ }^{14}$ In the concept of unio mystica, Calvin had the theological tool to thematise tradition, whilst his practice of using the appeal to tradition shows that he had an implicit consciousness of the union with the church in all ages and the importance of tradition. Due to the misuse of, and overemphasis on tradition, he did not explore it in his own theology, however. Therefore, the present use of the notion of unio mystica to thematise tradition can be seen as a retrieval of a reformed understanding of reality.

This union with Christ implies a participation in the transcendent reality in Christ (the belief that God is in a certain way present and recognisable in the historical body of Christ) and the expectation that union with the historical body of Christ implies sharing in God's reality and revelation - resisting immanent explanations of Christian doctrine. One other far-reaching conclusion can be made. Thinking and theologising from the perspective of the body of Christ implies that Christianity is not understood as a part of history, but history is understood as an aspect of Christianity (Williams 2005:ch. 6-7). Understanding history from the perspective of Christ also implies a distinction between history in general, the history of salvation and the history of the church in particular (cf. Van 't Spijker 1986:189).

13.Luther underlined the interpretation of Scripture in the communion of saints (Rothen 1990:79). For the reformed tradition, see Muller (1993:471-487) and Zwiep (2012:231). The fact that Calvin wrote about the church from the perspective of 'The External Means' in the fourth volume of his Institutes, illustrates that the
value of the church was more implicit than explicit.

14.Compare for the 'revival' about Calvin and the unio mystica, amongst others, Todd Billings (2005; 2008; 2011), Canlis (2010) and Horton (2007).
The implication of this understanding of the reality in Christ means that people in the history of the church are not only people from a foreign country with old-fashioned ideas and that the survival of Christianity therefore is only possible if old theological concepts are abandoned. Therefore, this understanding corrects the proud idea that believers from the 21st century know more than believers from former times as well as the idea that contemporary culture is more important for Christian theology than the body of Christ of all generations (Webster 2007:590). It also modifies the opinion that the suppressed voices were the only authentic voices in the past (Williams 2005:28). Another implication is the opinion that sound and useful contemporary theology does not need more than a recovery of an error in the past, for example nominalism or Enlightenment, as if there existed a pure Christian past (Webster ibid:596-597).

Without identifying ourselves unreservedly with the church of former times and not being sensitive for the peculiarity of the past, we can acknowledge the union with the catholic body of Christ and the necessity of this union in understanding God's revelation (cf. Van de Beek 2012:68-96). For centuries Christians have possessed the knowledge of God in Christ, they have thought about eternity, creation, redemption, the eschaton and the future, and they have experienced the struggle with sin and unbelief. This means that their thoughts are not less than our insights, but that in communion with the saints throughout time is comprehended the breadth and length, and depth and height and known the love of Christ (Eph 3:18-19). ${ }^{15}$

This means that Christian theology does not start de novo, but in the consciousness that the best and cumulative wisdom of

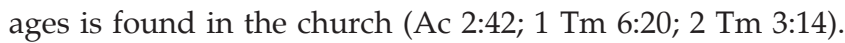
Therefore, it is a great disadvantage for the church today to isolate itself from the forefathers. Isolating the present church from the past church would be the same as saying: 'What do I have to do with my grandfather?' To understand oneself it is necessary to understand that traditional faith belongs to our present identity.

This insight characterises reformed tradition. When Voetius justified his frequent use of citations, he explained that he did not want to teach new and unusual things, but: ' $[w]$ ith the great theologians, I declare that I judge a road that is much walked on, a safe road'. ${ }^{16}$ In the 19th century, Groen van Prinsterer $(1848: 76,81)$ spoke about the 'historical faith'. He did not mean to divide the content of faith into a historical part and a saving part, but to express that the church shares in the faith of the foregoing generations. He (Groen van Prinsterer ibid:30,48) understood the church as a personality with one soul to believe and one mouth to speak, so that he interpreted the development of the confessed faith as an organic progress in which it was inconceivable not to confirm the historical faith.

15.Van den Belt (2011) indicates that catholicity coheres with the quality of Christianity.

16.'Cum magnis theologis protestor, me viam tritam viam tutam existimare' (Diatriba de coelo beatorum, Gorinchem 1665; De Niet 2002:i, vii). 
In the 20th century, C.S. Lewis (1996) argued in favour of the great worth of tradition. To widen our own limited outlook, we should prefer old books to new books, because in reading new books, we do not look beyond our own age. By reading old books, we can learn from the past and possibly correct errors in our own understanding. To illustrate his high esteem of the past, he (Lewis 1953:121-122) used the example of a map to describe Christian theology. The map is based on the experiences of multitudes of believers in many ages. Although the landscape of the Christian life is more than the map, without using the map we do not come to such a deep understanding of the landscape as with the use of a map.

These examples teach us that the Scriptures are given to the church in all ages and that interpreting the Scriptures should happen in dialogue with this church. The self-awareness of the church as a community across the centuries has a fourfold function. Firstly, it saves the church from revolutionary developments. In particular, the approach of Groen van Prinsterer reminds us that the church should not develop whilst breaking the tradition. ${ }^{17}$ Sensitiveness for traditional theology will help theology to develop in a sound way and to remain a catholic spirit in which the whole of truth functions. ${ }^{18}$ Secondly, the metaphor of Lewis shows that sensitiveness for traditional theology lifts up the church above the narrow view of its own time and gives a broader perspective to come to an understanding of faith. It is a blessing for the church in the present time that it does not have to discover all things, but that it stands on the shoulders of giants in history. Thirdly, the consciousness of the historic aspect of Christ's church is a comfort in times when and in cultures where Christian faith is diminishing. It strengthens believers' faith that they are not alone in their estimation of Christ. Fourthly, the historic consciousness of the Christian faith will enable the church to maintain an independent attitude in a culture in which renewal and new insights in science, technology and politics are esteemed as the guarantee of truth and success.

\section{Tradition as a catalyst for renewal}

The above-mentioned conclusion that tradition is a necessary aspect of the body of Christ may leave the impression that the church can only repeat tradition, preserve tradition and, as it were, be imprisoned by tradition (Van 't Spijker 1986:186). It is understandable that the recognition of the worth of tradition has often led to the practical implication that every theological renewal is withstood, that people study tradition to confirm their own position and that different movements claim to be the continuation of the same tradition, especially

\footnotetext{
17.I attended a lecture of Alister McGrath once in which he maintained that Calvinistic ecclesiology offers a dynamic for starting new churches, because this ecclesiology starts from the preaching of the Word and the ministry of the sacraments. According to his interpretation, the plurality of churches in Protestantism is implied in Calvinistic ecclesiology. For me, this is a very creative use of the Calvinistic tradition, lacking an understanding of the consciousness for the historic body of Christ in this tradition. In 2004, a part of the Nederlandse Hervormde Kerk did not enter the new Protestantse Kerk in Nederland, because they understood the denia of eternal predestination in The Leuenberg Agreement (GEKE-CPCE-CEPE 1973:3, 24-25) as a break with the reformed tradition.

18.This aspect of catholicity was most stressed in the early church (AH I.10.3). Article 2 in the Athanasian Creed (Schaff 1996) states that people who do not keep the truth complete and integral are lost. Vincent of Lerinum (PL 50:640) defined catholic as that which is always believed by everyone. The Heidelberg Catechism (Q. 54) went that which is always believed by everyone. The Heidelberg Catechism (Q. 54) went
one step further by confessing that the Christian church existed from the beginning of the world in union of true faith.
}

when the status quo is taken as the starting point in church and tradition without taking into account the conditions of the theological formulations.

This observation necessitates a further analysis of the character of tradition from the perspective of the theologoumenon of the body of Christ. It is important to notice that the approach of tradition from the perspective of the incarnation of Christ opens up a previously closed world. The eschatological and transcendental aspects of the incarnation of Christ imply that believers are not enclosed within the borders of human history or knowledge, but that God has revealed himself from outside and that believers have access to this knowledge beyond their human understanding (1 Cor 2:6-16).

This approach is fundamental and has far-reaching consequences. On the one hand, this approach implies a breakthrough in the Kantian concept, because, since Kant, it has been problematic to speak in an academic way about the transcendent reality of God. The effect of the separation between the transcendent and the immanent terrestrial reality is that speaking about God and about revelation is problematic, with the result that believers and theologians tend to think from a closed worldview and exalt the rational subject to the status of the epistemologically and metaphysically foundational (Webster 2007:589).

On the other hand, the approach of tradition from the perspective of the incarnation of Christ implies the openness of history in Christ and the contingent character of this history. Johannes Duns Scotus has clarified that this contingence - in contrast with classic Greek thinking - is not incidental, but structural. ${ }^{19}$ It is significant that this revolution in understanding history happened in the Christian tradition. Interpreting history from the perspective of God's creative work in the incarnation of Christ puts history in a completely different perspective.

The implications of this concept of interpreting history are profound (Mackay 1997:347-380). Whilst science presupposes general laws and repeatable events, the concept of an open history criticises the deterministic tendencies in this worldview, because this concept has room for unique events and can justify them. The great success of science has influenced modern culture and has made an appeal to the transcendent reality and unique events to be deemed suspicious. A closed worldview does not have any openness for the transforming of this creation into the new creation. These facts underline the necessity of an adequate concept of history. The contemporary developments in quantum mechanics point in the same direction and weaken the deterministic understanding of a world that is enclosed in itself.

Another further implication of this concept of historical contingency is that speaking about God's acts should not necessarily imply a deterministic understanding of history. For God, as the grandmaster chess player of history, it

19.For Duns Scotus's concept of 'synchronic freedom', see Vos $(1981 ; 2006)$ and Vos et al. (1994). Mackay (2000:29-34) applies these insights to the philosophy of history. 
would have been possible to lead the development of history in another channel. ${ }^{20}$ This is also true for the development of Christian tradition. If we think of the development of theology in tradition as a line, the development could not have been different and the church today is responsible to continue the straight line of tradition. Thinking from the contingent perspective implies that history is not understood as a line, but as a line in a plane area. In the plane area of history, God has drawn a line, but God had the ability to draw that line through another place, or to draw it in another direction today.

The contingent character of history implies the unique character of every moment in history, especially in the history of the church as the body of Christ - the greatest factor in history and the greatest factor determining history. This insight is revolutionary within the self-understanding of the Christian tradition. During the reformation, Luther and Calvin could - although they understood the reformation as the working of the Word - too easily claim tota noster [completely ours] with Augustine, because they did not discount that the past and the present have their own historical context and are answers to specific unrepeatable situations (Mackay 2000:52). Therefore, the past cannot be copied without transcription errors. Or to use another metaphor: whilst sheep can be cloned, the past cannot be cloned. The consciousness of the dynamic character of the past is an antidote to the idea that tradition is a fossil.

The dynamic character of theological tradition also leads to the understanding that every time and context adds a link to the chain, so that theology continues and develops without thinking in terms of revolution or modernisation. Theological retrieval does not mean striving for the repetition of history, but does require sensitivity that in different situations different aspects are relevant and the different aspects get a different application. Studying historical theology in the context of its culture and context opens the possibility that whilst hearing the voices of the past - old theological debates get a fresh application and are reframed in the present (Todd Billings 2011:2).

In specific historic circumstances, the depth and relevance of certain doctrines is clearly and convincingly proven. Theologians of retrieval (Todd Billings 2011:4-5) are conscious that theologians of an earlier period have possibilities that exceed the possibilities in the present. That makes the conversation with former theologians necessary and helpful. Historical distance can be helpful to distinguish between the message of the Bible and the influence of the old culture. Reading the Bible with premodern theologians will sharpen our own mind for presuppositions then and now. So an interpretatio continua [continuous interpretation] of Scripture develops.

We read the Scriptures not only with Christians of former cultures, but also in fellowship with Christians in other cultures in our own time. In our individualistic western society, we tend not to be sensitive for kinship structures in

20.Calvin (Inst. 1.17.1) gives an example that heavy adversities in the lives of believers will not bring distrust in the faithfulness of God, because he is above history.
Scripture (cf. 2 Sm 24:17; Dn 9:5). The communion of saints with Christians in Africa will help us to be sensitive for these aspects and, in this way, come to a deeper understanding of the Word of God.

Perhaps a metaphor is helpful to understand the use of tradition for understanding Scripture for contemporary theology (cf. Van den Toren 2011:45). If we should understand historic doctrine as the foundation of the building of church and theology, going back to the tradition would imply the demolition of the historic building of the church and the rebuilding of it again and again. The metaphor of reading a book is more convenient. When we start reading a book, we have our own concept about a certain idea. Reading the book is done in a critical way. Perhaps we do not accept the complete presentation, but we accept certain insights and give them a place in our own understanding of reality. In this way, we read the understandings of Scripture of the communion of saints. Where they differ, our interest is awakened, we test our own understanding and we apply new insights in our own understanding.

John Webster (2007) gave several examples of such new understandings of Scripture in the historic church. Wellknown is the revival of Trinitarian theology. Whilst in many decennia Trinitarian theology was judged as a speculative aspect in Christian theology, in the last decennia the retrieval of Trinitarian theology is sometimes observed in such a way that several authors judge it to be the cornerstone in theology.

Also, the doctrines of the church and the creation are reconsidered. Luther's doctrine of the bondage of the will and the theology of the cross has many fresh applications in contemporary culture and theology. We can imagine that in postmodern culture, with an openness for a higher spiritual world, a reconsideration of angelology is relevant. In reformed theology, the theological concept of unio mystica is an example of the relocation of a traditional theme. Although Calvin already had the sensitiveness for a broader application of this theologoumenon, in his doctrine of the Lord's Supper for example, the working out of this doctrine remained limited..$^{21}$

It is conceivable that the renewal of the concept of mystical union with Christ can be made useful for several other novel applications. Whilst Irenaeus used this concept against the Gnostic tendency to deny the goodness of creation, Calvin used this concept to do justice to the transcendence of God in the context of humanism (Canlis 2010:21-22). Perhaps Canlis's (ibid:45-50, 159-160) central discovery of Calvin's use of unio mystica in speaking about ascending with Christ to heaven may be explored in our context to come to a deeper understanding of the transcendent character of Christ's kingdom, on the one hand, and to develop a fresh theology of spirituality in the many contemporary questions on the other hand..$^{22}$

21.Inst. 3.15.5 offers an example of a broader use of the communicatio cum Christo. The union with Christ (Janse 2008) was also used for understanding and explaining The union with Christ
the Lord's Supper,

22.This approach is related to the plead of De Bruijne (2012) to underline to contrast between the kingdom of God and the earthly realm in the attitude of Christians towards politics. 
Todd Billings (2011:15-34) has shown how the concept of the unio cum Christo [spiritual union with Christ] can be explored in several other theological themes, for example to withstand deistic views of God, to understand God's accommodation in his revelation and in our communion with the incomprehensible God (Todd Billings ibid:63-94), as well as to be sensitive for the problem of social justice in this world (Todd Billings ibid:95-122). These examples are illustrations of how classic theological concepts can be reframed in the present cultural and ecclesiological context.

The examples of Tod Billings indicate that a theological concept can have sociological applications and effects. We can carry this insight further. It is a striking fact from the history of the church that the Great Awakening was one of the instruments in the abolition of slavery. During the Great Awakening (Marsden 2003:258), Black slaves and White people were united in the Lord's Supper in the congregation of Northampton during the ministry of Jonathan Edwards. In this spiritual revival there was a new understanding of the equality of the different races. This insight had a great political, cultural and sociological effect until the present day so that we cannot even imagine thinking as our forefathers did before the Great Awakening. This is only one example how living the eschatological life affords the possibility to criticise existing institutions and to transform them. We can imagine that the Christian insight of the equality of the races and other theological concepts can have fresh applications for society today.

One question remains, namely the relation between tradition and renewal, because it is not enough to state that the integrity of Christ implies, on the one hand, a traditionalism that is not against renewal and, on the other hand, a renewal that is not against tradition. Cyprian (1844-1864:1129) provided a direction: Nihil innovetur nise quod traditum est [nothing shall be renewed except what is transmitted in tradition]. This rule implies the denial of an unqualified traditionalism and an unqualified 'renewalism', because in a different context the repetition of tradition can appear to be a lie - every context asks for a fresh application of tradition. This brings us to the conclusion that neither tradition nor renewal can be an aim in itself, but that sound theological renewal does not consist in new theology, but in a fresh application of the apostolic and catholic truth.

\section{Conclusion}

This article leads to the following conclusions: Firstly, whilst the principle of sola scriptura can never be relativised, it has shown that the opposite of this principle is the weakness of a subjective appeal to Scripture. At the time of the reformation, this problem was not explicitly solved. Secondly, the concept of the church as the body of Christ in all ages appears to be a remedy against subjectivism and it reminds the church of the present day to remain faithful to the faith of the church and to study to get a thorough knowledge and understanding of the Christian tradition. Thirdly, it appears that the best and cumulative wisdom of many ages opens up storehouses of wisdom for new applications and fresh answers in times of crisis, as well as functions as a catalyst for renewal in times of transition. ${ }^{23}$

These conclusions imply a qualified relationship between tradition and renewal: every theological renewal implies the catholic truth. Not all problems are solved with this conclusion. Several questions remain, such as the boundary of tradition and the integrity of renewal, but this concept can help the church to reflect upon and to be conscious of the relationship with tradition.

\section{Acknowledgements Competing interests}

The author declares that he has no financial or personal relationship(s) that may have inappropriately influenced him in writing this article.

\section{References}

Bartlett, D.L., 1993, Ministry in the New Testament, Fortress Press, Minneapolis.

Bavinck, H., 2003, Reformed Dogmatics, Baker Academic, Grand Rapids.

Calvin, J., 1559, 'Institutes', in G. Baum et al. (ed.), Corpus Reformatorum, vol. XXX, 4 th edn.

Calvin, J., 1863-1900, 'Joannis Calvini opera quae supersunt omnia', in G. Baum et al. (ed.), Corpus Reformatorum, C.A. Schwetschke et filium, Brunsvigae.

Canlis, J., 2010, Calvin's ladder: A spiritual theology of ascent and ascension, Eerdmans, Grand Rapids.

Community of Protestant Churches in Europe (GEKE-CPCE-CEPE), 1973, The Leuenberg Agreement, viewed 02 May 2012, from http://www.leuenberg.net/sites/default/ files/media/pdf/Publications/Konkordie-en.pdf

Cyprian, 1844-1864, Epistola 74.2, in J-P. Migne (ed.), MPL 3, Patrologia Latina, Garnier, Parisiis.

De Bruijne, A.L.Th., 2012, "'A banner that flies across this land": An interpretation and evaluation of Dutch evangelical political awareness since the end of the twentieth century', in C. van der Kooi, E. van Staalduine-Sulman \& A.W. Zwiep (eds.), Evangelical Theology in Transition, pp. 86-130, vU University Press, Amsterdam.

De Niet, C.A., 2002, De praktijk der godzaligheid, De Banier, Utrecht.

Graafland, C., 2001, Bijbels en daarom gereformeerd, Boekencentrum, Zoetermeer.

Groen van Prinsterer, G., 1848, Het regt der hervormde gezindheid, Johannes Müller, Amsterdam.

Helm, P., 2004, John Calvin's ideas, Oxford University Press, Oxford. http://dx.doi. org/10.1093/0199255695.001.0001

Horton, M., 2007, Covenant and salvation: Union with Christ, Westminster John Knox, Louisville.

Irenaeus, 1844-1864, Adversus Haeresus, in J-P. Migne (ed.), MPG 7, Patrologia Graeca, Garnier. [=AH]

Janse, W., 2008, 'Calvin's Eucharistic Theology: Three dogma-historical observations', in H.J. Selderhuis (ed.), Calvinus sacrarum literarum interpres, pp. 37-69, Vandenhoeck \& Ruprecht, Göttingen. (Reformed Historical Theology series).

Lewis, C.S., 1953, Mere Christianity, Geoffrey Bles, London.

Lewis, C.S., 1996, 'Introduction', in St. Athanasius, On the Incarnation: De Incarnatione Verbi Dei, pp. 3-12, St. Vladimir's Seminary Press, New York.

Lohse, B., 1995, Luthers Theologie in ihrer historischen Entwicklung und in ihrem systematischen Zusammenhang, Vandenhoeck \& Ruprecht, Göttingen.

Luther, M., 1883-1997, D. Martin Luthers Werke: kritische Gesamtausgabe (Weimarer Ausgabe), Hermann Böhlau, Weimar. [=WA]

Mackay, E., 1997, Geschiedenis bij de bron. Een onderzoek naar de verhouding van christelijk geloof en historische werkelijkheid in geschiedwetenschap, wijsbegeerte en theologie, Merweboek, Sliedrecht.

Mackay, E., 2000, Gedenkstenen in de Jordaan. Opstellen over geschiedenis, traditie en cultuur, Groen, Heerenveen.

Marsden, G.M., 2003, Jonathan Edwards: A life, Yale University Press, New Haven.

Meijering, E.P., 1985, Die Hellenisierung des Christentums im Urteil Adolf von Harnacks, North Holland Publishing Company, Amsterdam/Oxford/New York. PMCid:PMC2713910

23.Bartlett (1993:181) underlined that the ministry has to look to our fathers and mothers in the Faith, finding in those older traditions the resources we need for our own time'. 
Melanchthon, Ph., 1521, 'Loci Communes', Corpus Reformatorum, vol. XXI.

Muller, R.A., 1993, Post-Reformation Dogmatics 2: Holy Scripture. The cognitive foundation of theology, Baker Academic, Grand Rapids.

Muller, R.A. (ed.), 2000, 'Scholasticism in Calvin: A question of relation and disjunction', in The unaccommodated Calvin. Studies in the foundation of a theological tradition, pp. 39-61, Oxford University Press, New York/Oxford.

Pannenberg, W. (ed.), 1979, 'Die Krise des Schriftprinzips', in Grundfragen systematischer Theologie. Gesammelte Aufsätze, pp. 11-21, Vandenhoeck \& Ruprecht, Göttingen.

Rothen, B., 1990, Die Klarheit der Schrift. Martin Luther: die wiederentdeckten Grundlagen, Vandenhoeck \& Ruprecht, Göttingen.

Schaff, P. (ed.), 1996, 'Athanasian Creed', The Creeds of Christendom, 6th edn., vol. II, pp. 66-71, Baker Academic, Grand Rapids.

Steinmetz, D.C., 1995, Calvin in Context, Oxford University Press, New York/Oxford.

Steinmetz, D.C., 1999, 'The scholastic Calvin', in C.R. Trueman \& R.S. Clark (eds.), Protestant Scholasticism. Essays in Reassessment, pp. 16-30, Paternoster Press, Carlisle.

Todd Billings, J., 2005, 'United to God through Christ: Assessing Calvin on the question of deification', in Harvard Theological Journal 98(3), 315-334.

Todd Billings, J., 2008, Calvin, participation, and the gift: The activity of believers in union with Christ, Oxford University Press, Oxford.

Todd Billings, J., 2011, Union with Christ. Reframing theology and ministry for the church, Baker, Grand Rapids.

Van de Beek, A., 2012, Lichaam en Geest van Christus. De theologie van de kerk en de Heilige Geest, Meinema, Zoetermeer

Van den Belt, H., 2007, 'Die gesproken heeft door de profeten', Theologia Reformata 50(4), 346-360.

Van den Belt, H., 2008, Autopistia. The Self-Convincing Authority of Scripture in Reformed Theology, Brill, Leiden. http://dx.doi.org/10.1163/ej.9789004163072.i-384

Van den Belt, H., 2011, 'De katholiciteit van de kerk als kwaliteit van het christendom', Theologia Reformata 54(3), 270-287.
Van den Brink, G. and C. van der Kooi, 2012, Christelijke dogmatiek. Een inleiding, Boekencentrum, Zoetermeer.

Van den Toren, B., 2011, Christian apologetics as cross-cultural dialogue, T\&T Clark, London.

Van der Kooi, C., 1999, Hinkelen binnen de lijnen, Kok, Kampen. PMCid:PMC1377896

Van der Kooi, C., 2006, Tegenwoordigheid van Geest. Verkenningen op het gebied van de leer van de Heilige Geest, Kok, Kampen. PMCid:PMC3374440

Van der Kooi, C., 2008, 'The appeal to the inner testimony of the Spirit, especially in H. Bavinck', Journal of Reformed Theology 2(2008), 103-112. http://dx.doi. org/10.1163/156973108X306209

Van 't Spijker, W., 1981, Triptiek van de geschiedenis. De verhouding tussen wereld-, heils- en kerkgeschiedenis, Oosterbaan \& Le Cointre, Goes.

Van't Spijker, W., 1986, Reformatie en geschiedenis, Oosterbaan \& Le Cointre, Goes.

Vincent of Lerinum, 1844-1864, Commonitorium 1.2 in PL 50, J-P Migne (ed.), Patrologia Latina, Garnier.

Vos, A., Veldhuis, H., Looman-Graaskamp, A.H., Dekker, E. \& Den Bok, N.W., 1994, Johannes Duns Scotus: Contingency and Freedom. Lectura I 39, Kluwer, Dordrecht/ Boston.

Vos, A., 1981, Kennis en noodzakelijkheid. Een kritische analyse van het absolute evidentialisme in wijsbegeerte en theologie, Kok, Kampen. PMCid:PMC493835

Vos, A., 2006, The philosophy of John Duns Scotus, Edinburgh University Press, Edinburgh. http://dx.doi.org/10.3366/edinburgh/9780748624621.001.0001

Webster, J. (ed.), 2007, 'Theologies of retrieval', Oxford handbook of systematic theology, pp. 583-599, Oxford University Press, Oxford.

Williams, R., 2005, Why study the past? The quest for the historical church, Darton, Longman \& Todd, London.

Zwiep, A.W., 2012, 'The Wesleyan Quadrilateral reconsidered: Wesley meets Gadamer', in C. van der Kooi, E. van Staalduine-Sulman \& A.W. Zwiep (eds.) Evangelical theology in transition, pp. 223-246, VU University Press, Amsterdam. 